\title{
Sistem Operasional Akad Ijarah Pada Kinerja Tukang Bangunan Menurut Ekonomi Islam di Desa Kertagena Tengah Kabupaten Pamekasan
}

\author{
Agung Fakhruzy \\ Institut Agama Islam Negeri Madura \\ Email :agungfakhruzy@gmail.com
}

\begin{abstract}
The house-building business in the Central Kertagena Village is one of the businesses that are of concern to the community by using a timing system with "Ijarah" payments. The homeowner gives a verbal description to the builder then gives according to the specified promise. Parties in association do not know about contracts Many conflicts occur due to rules that must be followed by both parties not working properly. And also the compilation of goods has been completed does not match the owner and the builder did not want to admit his mistakes. Based on this, there are two that are the focus of this study, first: How is the application of the ijarah contract to the performance of builders in the village of Central Kertagena? The results showed that in the implementation of the contract at the beginning of the agreement only based on verbal and not published in accordance with the problem at the end after the completion of the contract. Then at 07:00 WIB - 04:00 WIB. However, it is satisfied to repair the building that was built over that time and stopped before the traffic jams, as well as to repair the house and cost more. In addition, the lack of clarity in the good model of the house model of the homeowner ordered the desired goods only by word alone and the builder requires no need to be correct so that more causes problems. When the goods are finished it is not suitable for the owner and the builder does not want to admit his mistakes.
\end{abstract}

Keywords : Ijarah agreement, builder, Islamic economics

Abstrak : Usaha proyek pembangunan rumah di Desa Kertagena Tengah merupakan salah satu usaha yang menjadi kebiasaan mayoritas masyarakat dengan menggunakan sistem penentuan waktu dengan pembayaran "Ijarah". Yakni pihak pemilik rumah memberikan gambaran secara lisan kepada tukang bangunan kemudian memberikan upah sesuai perjanjian yang ditentukan. Pihak yang berserikat tidak mengetahui secara benar mengenai akad Ijarah sehingga pelaksanaannya masih kurang benar. Sering terjadi konflik diakibatkan perjanjian yang buat oleh kedua belah pihak tidak berjalan dengan semestinya. Dan ketika barangnya sudah selesai pemiliknya merasa tidak cocok dan tukang bangunan tidak mau mengakui kesalahannya. Berdasarkan hal tersebut, maka ada dua yang menjadi fokus dalam penelitian ini,: pertama, Bagaimana penerapan akad ijarah pada kinerja tukang bangunan di desa Kertagena Tengah?, kedua, Bagaimana tinjauan Ekonomi Islam pada kinerja tukang bangunan di desa Kertagena Tengah?. Hasil penelitian menunjukkan bahwa dalam melaksanakan akad di awal perjanjian hanya berdasarkan lisan dan tidak tertulis akibatnya membuka peluang masalah diakhir setelah selesai kontrak. Kemudian dalam melaksanakan tanggung jawabnya tidak secara maksimal misalnya jam kerja yang seharusnya dimulai dari 07.00 WIB - 04.00 WIB. Namun, kenyatannya tukang bangunan memulai kerjanya di atas waktu tersebut dan berhenti sebelum jam tersebut, sehingga memperlambat terhadap penyelesaian rumah dan memakan biaya yang lebih banyak. Selain itu, ketidakjelasan akad baik dari model rumah pemilik rumah memesan barang 
yang diinginkan hanya dengan perkataan saja dan tukang bangunan menangkap tidak begitu memahami betul sehingga banyak yang menimbulkan permasalahan. Ketika barangnya sudah selesai tidak cocok pada pemiliknya dan tukang bangunan tidak mau mengakui kesalahannya.

Kata Kunci : Akad Ijarah, Tukang Bangunan, Ekonomi Islam

\section{A. Pendahuluan}

Agama Islam merupakan sistem kehidupan yang bersifat komprehensif dan universal yang mengatur semua aspek, baik sosial, ekonomi, dan politik maupun kehidupan yang bersifat spiritual. Islam bersifat komprehensif artinya yang mengatur semua aspek kehidupan manusia, baik aqidah, ibadah, akhlak maupun muamalah. Salah satu ajaran yang sangat penting adalah bidang muamalah atau iqtishadiyah (Ekonomi Islam). Sedangkan Islam bersifat universal artinya syariah Islam itu dapat diterapkan dalam setiap waktu dan tempat sampai datangnya hari kiamat nanti.

Menurut Muhammad baqir as-Sadr, ekonomi Islam adalah semuah ajaran atau doktrin dan bukannya ilmu murni (Science), karena apa yang terkandung dalam ekonomi Islam bertujuan memberikan sebuah solusi hidup yang paling baik, sedangkan ilmu ekonomi hanya mengantarkan kita kepada pemahaman bagaimana kegiatan ekonomi berjalan. ${ }^{1}$

Secara umum tujuan dalam ekonomi Islam adalah untuk mencapai kesejahteraan bagi masyarakat yang adil dengan menghilangkan bentuk ketidakadilan dan ketidak seimbangan. Terdapat tiga pilar ekonomi syariah, yaitu keadilan, keseimbangan, dan kemaslahatan. Keadilan dalam arti kegiatan perekonomian yang menghindari riba, maisir, gharar, zalim dan haram. Keseimbangan adalah kegiatan invertasi yang dilakukan di sektor riil untuk meningkatkan kesejahteraan masyarakat dengan menekankan kebersamaan dalam memperoleh manfaat (kemaslahatan). ${ }^{2}$

Dari pandangan fiqh, kegiatan ekonomi bukanlah termasuk bab ibadah mahdhah, melainkan bab muamalah. Oleh karena itu, berlaku kaidah fiqh yang menyatakan bahwa Ash fi al Muamalah (Ghair al-'Ibadah) al-ibaha, illaidza ma dalla al-dalilala khilafihi, yakni suatu perkara muamalah pada dasarnya diperkenankan (halal) unutk dijalankan, kecuali jika ada bukti yang larangannya berasal dari sumber agama (kitab dan sunnah). Tiap-tiap yang dikerjakan karena Allah masuk dalam lapangan ibadah.selain itu, bidang muamalah juga berkenan dengan aturan terkait aktivitas seseorang dengan seorang lainnya dalam memenuhi Kebutuhannya. ${ }^{3}$

Muamalah adalah salah satu aspek penting selain ibadah yang menjadi bagian dari aktivitas manusia. Fiqh muamalah adalah seperangkat aturan yang berkaitan dengan aktivitas sosial manusia, baik berkaitan dengan harta (maliyah) atau tidak berikatan dengan harta (ghairu maliyah) seperti pidana, perdata dan ketatanegaraan. ${ }^{4}$

Selain mempunyai cakupan luas dan fleksibel, muamalah tidak membeda-bedakan antara Muslim dan non Muslim. Dalam ajaran Islam, kita tidak boleh tidak menyenangi dunia, dengan melarikan diri kealam akhirat dan hanya berdo'a saja di masjid. Kita

\footnotetext{
${ }^{1}$ Fatillah D Koem, “Tinjauan Ekonomi Islam Terhadap Jasa Profesi Tukang Parkir (Studi Kasus Pasar 45 Kota Manado)," Jurnal Ilmiah Al-Syir'ah 12, no. 1 (2014): 1.

${ }^{2}$ Septarina Budiwati, “Akad Sebagai Bingkai Transaksi Bisnis Syariah,” Jurnal Jurisprudence2 7, no. 2 (2017): 153.

${ }^{3}$ Ibid.

${ }^{4}$ Firman Setiawan, “Al-Ijarah Al-A’mal Al-Mustarakah Dalam Perspektif Hukum Islam,” Jurnal Ekonomi dan Keuangan Islam 1, no. 2 (2015): 105.
} 
diperintahkan untuk berusaha menggunakan semua kapasitas atau potensi yang ada pada diri masing-masing, sesuai dengan kemampuan. Manusia sebagai makhluk sosial tidak terlepas dari berinteraksi dengan sesama, sehingga manusia dalam memenuhi kebutuhan hidupnya selalu kerjasama antara satu pihak dengan pihak yang lain.

Dalam transaksi bermuamalah, syari'ah Islam memiliki peran penting yaitu sangat menekankan arti pentingnya keadilan dalam tindakan kegiatan bermuamalah sesama manusia, tidak boleh berlaku curang, melakukan perbuatan keji, dan selalu bersikap seimbang dalam melakukan perbuatan muamalah dan kontrak terhadap sesuatu hal yang diinginkannya karena menurut Islam, adil merupakan norma paling utama dalam seluruh aspek perekonomian. ${ }^{5}$ Usaha yang sesuai dengan syariat Islam adalah yang tidak menyalahi syariat, orang yang melakukan kegiatan ekonomi, mengetahui hal-hal yang sah dan tidak sah, juga hal-hal yang diharamkan dan dihalalkan sehingga tidak menimbulkan kerusakan dan kerugian bagi orang lain. ${ }^{6}$

Kenyataan menunjukkan bahwa diantara sebagian manusia yang memiliki keahlian tapi tidak bisa menjalankan secara baik, ada juga yang mempunyai keahlian tetapi dia ingin membantu orang lain yang mempunyai keahlian untuk menambah pendapatan mereka. Seorang mukmin yang bekerja untuk memenuhi kebutuhan hidup dalam pandangan Islam dinilai sebagai ibadah yang disamping memberikan perolehan material juga mendatangkan pahala.

Islam mendorong manusia untuk bekerja dan berjuang untuk mendapatkan materi atau harta dengan berbagai cara, asalkan mengikuti aturan yang telah ditetapkan oleh syariat, hal ini dijamin oleh Allah Swt bahwa Dia telah menetapkan rezeki setiap makhluk yang diciptakannya, Al- Bahi menyatakan bahwa bekerja adalah sarana mencapai rezeki dan kelayakan hidup, jika seseorang mempunyai kekayaan dan dapat hidup tanpa bekerja maka ia akan dapat memahami nilai-nilai kemanusiaannya dan tidak mengetahui tugas hidup yang sebenarnya. ${ }^{7}$

Untuk mendirikan suatu usaha diperlukan keahlian dibidang-bidang tertentu. Tidak sedikit orang-orang mempunyai keahlian yang memadai dan keinginan yang kuat untuk berusaha tetapi mereka tidak mempunyai keuangan yang mendukung untuk membuka usaha hanya saja mempunyai kemampuan dari dirinya sendiri untuk memenuhi kebutuhan dengan keahliannya itu.

Pada kasus ini para tukang bangunan memanfaatkan keahlian jasanya untuk membantu pada pihak yang membutuhkan khususnya yang mau membangun rumah. Sudah merupakan kodratnya bahwa manusia tidak bisa hidup sendiri, harus hidup bersama dalam suatu masyarakat yang terorganisasi untuk mencapai tujuan bersama. Agar tujuan mereka tersebut tercapai sebagaimana mestinya dan dalam usahanya tidak selalu berbentur kepentingan maka diperlukanlah suatu Norma yang mengaturnya. Dengan adanya kerjasama yang saling mengisi ini maka perkongsian ini maju secara meyakinkan.

Di dalam perekonomian yang marak sekarang ini adalah dengan menggunakan sistem akad ijarah tidak hanya di perbankan saja tetapi dikalangan masyarakat juga menerapkan hal tersebut. Dengan dijalankannya akad ini membantu satu dengan lain,

\footnotetext{
${ }^{5}$ Yusuf Qardhawi, Norma Dan Etika Ekonomi Islam (Jakarta: Gema Insani Press, 2001).

${ }^{6}$ HM Hanafiah, "Akad Jual Beli Dalam Tradisi Pasar Terapung Masyarakat Banjar," Jurnal Pemikiran Islam 15, no. 1 (2015): 203.

${ }^{7}$ Muhammad Syahrial Yusuf, Meraih Keajaiban Rezeki Dengan Wirausaha (Jakarta: Erlangga, 2013).
} 
yang tidak mempunyai keahlian terbantu oleh yang mempunyai keahlian dengan pondasi tidak merugikan salah satu pihak. Sesungguhnya agama Islam telah mengajarkan bagaimana kerjasama (berserikat) secara benar tidak memberatkan salah satu pihak serta saling menguntungkan serta terhindar dari riba. ${ }^{8}$

Berserikat dapat dilakukan dengan lembaga ataupun perorangan. Salah satu kegiatan yang diperbolehkan adalah akad Ijarah. Ijarah adalah akad untuk memanfaatkan jasa, baik jasa atas barang ataupun jasa atas tenaga kerja. Bila digunakan untuk mendapatkan manfaat barang maka disebut dengan sewa menyewa, sedangkan jika digunakan untuk mendapat tenaga kerja disebut upah mengupah. ${ }^{9}$

Istilah ijarah sesungguhnya tidak muncul pada masa Nabi Muhammad SAW, tetapi jauh sebelum Nabi lahir pun sudah ada. Usaha proyek pembangunan rumah di Desa Kartagena Tengah adalah usaha yang menjadi kebiasaan dengan menggunakan sistem penentuan waktu dengan pembayaran spontan. Yakni pihak pemilik rumah memberikan gambaran secara lisan kepada tukang bangunan kemudian memberikan upah kepada tukang itu sesuai perjanjian yang ditentukan baik harian, mingguan atau bulanan.

Gambaran tersebut dijelaskan kepada pihak kedua atau orang yang memiliki keahlian. Usaha ini rata-rata dilakukan oleh masyarakat yang tergolong ekonomi lemah. Kegiatan ini diharapkan kedua belah pihak dapat sama-sama memperoleh keuntungan antara pemilik dengan pembuat. Sehingga para anggota bisa terbantu untuk memenuhi kehidupan ekonominya. Kurangnya pendidikan, keterampilan dan pemahaman sehingga mengakibatkan rendahnya pendapatan keluarga. Oleh karena itu dengan adanya usaha proyek pembangunan ini diharapkan mampu meningkatkan pendapatan ekonomi keluarga.

Dalam perkembangan perekonomian saat ini sistem ijarah tidak hanya digunakan dalam perbankan saja, tetapi juga dipakai pada usaha perekonomian lainnya guna untuk meningkatkan perekonomian. Meskipun usaha ini masih kecil, dan sebagian perancang ada yang kurang mengetahui sistem yang benar dan baik tetapi masyarakat masih mau mengikuti usaha ini.

Selain itu, pihak yang berserikat tidak mengetahui secara benar mengenai akad ijarah sehingga pelaksanaan yang dijalankan masih kurang benar. Seperti halnya kedua belah pihak dalam melaksanakan akad di awal perjanjian hanya berdasarkan lisan dan tidak disertai dengan keterangan secara tertulis akibatnya membuka peluang masalah diakhir setelah selesai kontrak. Kemudian, pihak pemilik rumah memberikan penjelasan kepada tukang bangunan dengan gambaran isyarat tidak memberikan gambar yang jelas baik dari model, luas dan lain-lain sesuai yang diinginkan.

Sering terjadi konflik diakibatkan aturan-aturan yang harus diikuti oleh kedua belah pihak tidak berjalan dengan semestinya. Fenomena yang terjadi di masyarakat khususnya tukang bangunan yang mayoritas dalam melaksanakan tanggung jawabnya tidak secara maksimal misalnya jam kerja yang seharusnya dimulai dari 07.00 WIB - 16.00 WIB. Namun, didunia nyata mayoritas tukang bangunan memulai kerjanya di atas waktu tersebut dan berhenti sebelum jam tersebut, sehingga memperlambat juga terhadap penyelesaian rumah dan memakan biaya yang lebih banyak.

Berserikat dalam bentuk pesanan sudah tidak jarang lagi kita temui dari kota sampai

${ }^{8}$ Chaudhry Muhammad Sharif, Sistem Ekonomi Islam (Jakarta: Kencana, 2012), h. 64.

9 Ajeng Mar'atus Solihah, "Penerapan Akad Ijarah Pada Pembiayaan Multijasa Dalam Perspektif Hukum Islam,” Jurnal Hukum Bisnis Islam 6, no. 1 (2014): 107. 
ke pelosok desa. Sering kali kita jumpai pemilik rumah memesan barang yang diinginkan hanya dengan perkataan saja dan tukang bangunan menangkap tidak begitu memahami betul sehingga banyak yang menimbulkan permasalahan. Ketika barangnya sudah selesai tidak cocok pada pemiliknya dan tukang bangunan pun tidak mau mengakui kesalahannya. Dari hal tersebut perlu ditegaskan diawal akad terkait dengan kegiatan yang dilakukan untuk menghindari dari hal-hal yang tidak diinginkan pada akhir akad.

B. Metode Penelitian

Penelitian ini menggunakan pendekatan kualitatif yang mengkaji tentang bagaimana seseorang mengalami suatu kejadian atau fenomena. Dalam jenis ini, peneliti diharuskan mendekati objek dengan pikiran polos tanpa asumsi, praduga, prasangka ataupun konsep. ${ }^{10}$

Penelitian ini dirancang dengan menggunakan pendekatan kualitatif. Penelitian kualitatif ini mempunyai arti sebagai penelitian yang bermaksud untuk memahami fenomina tentang yang dialami oleh subjek penelitian, misalnya perilaku, persepsi, motivasi tindakan dan lain sebagainya. ${ }^{11}$

Peneliti menggunakan pendekatan kualitatif kerena peneliti ingin mengetahui bagaimana menerapkan akad ijarah pada kinerja tukang bangunan menurut Ekonomi Islam di Desa Kertagena Tengah Kabupaten Pamekasan.

Sedangkan jenis penelitian yang digunakan, berdasarkan pendekatan di atas adalah analisis deskriptif yang bersifat deskripsi artinya pemaparan atau penggambaran dengan kata-kata secara jelas dan terperinci. Adapun peristiwa yang menjadi penelitian kali ini di Desa Kertagena Tengah Kecamatan Kadur yaitu Sistem Operasional Akad Ijarah pada Kinerja Tukang Bangunan menurut Ekonomi Islam di Desa Kertagena Tengah Kecamatan Kadur artinya bagaimana mengetahui kesesuaian antara aturan yang benar menurut syariah dan yang terjadi di lapangan.

\section{Hasil dan Pembahasan}

\section{Penerapan Akad Ijarah pada Kinerja Tukang Bangunan Menurut Ekonomi Islam di Desa Kertagena Tengah Kabupaten Pamekasan.}

Istilah akad berasal dari bahasa Arab, yaitu $a l$ - 'aqdu yang berarti perjanjian yang tercatat atau kontrak. Sayyid Sabiq dalam kitabnya fikih sunah memberikan arti bahwa akad adalah suatu ikatan dan kesepakatan. Adapun sumber lain ada yang mengartikan bahwa akad sebagai pertalian ijab dan kabul sesuai dengan kehendak syariat yang berpengaruh pada suatu objek perikatan. ${ }^{12}$

Ada beberapa pengertian akad secara etimologis, yaitu: 1) mengikat dan mengumpulkan dalam dua ujung tali kemudian mengikat salah satunya dengan jalan lain sehingga sambung untuk menjadi suatu benda. 2) sambungan yang memegang kedua ujung itu dan mengikat. 3) janji sebagaimana disinggung dalam Al qur'an surat Ali Imran ayat: 76 yang artinya: "bukan demikian, sebenarnya siapa saja yang mnepati janji yang telah dibuatnya dan bertakwa maka sesungguhnya Allah menyukai

10 Zainollah and Fakhruzy Fakhruzy, "Penundaan Pembayaran Upah Pekerja Di Pabrik Sandal UD. Nusantara Desa Pasanggar Kecamatan Pegantenan Kabupaten Pamekasan Perspektif Hukum Islam," Jurnal Hukum Ekonomi Islam Indonesia 1, no. 1 (2019): 21.

${ }^{11}$ Lexy J Moleong, Metodologi Penelitian Kualitatif (Bandung: PT Remaja Rosdakarya, 2006), h.6.

${ }^{12}$ Muhammad Yunus, Fahmi Fatwa Rosyadi Satria Hamdani, and Gusti Khairina Shofia, "Tinjauan Fikih Muamalah Terhadap Akad Jual Beli Dalam Transaksi Online Pada Aplikasi Go-Food," Jurnal Ekonomi dan Keuangan Syariah 2, no. 1 (2018): 146. 
orang-orang yang bertakwa". ${ }^{13}$

Kata "aqd" mengacu pada terjadinya dua perjanjian atau lebih yaitu bila seseorang mengadakan janji kemudian ada orang lain yang menyetujui janji tersebut sehingga ada dua orang yang salaing terikat pada perjanjian itu. Dari uraian di atas ada beberapa tahap yaitu: 1) perjanjian . 2) persetujuan dua buah perjanijan atau lebih dan 3) perikatan. ${ }^{14}$

Secara etimologi, ijarah adalah upah sewa yang diberikan kepada seseorang yang telah mengerjakan suatu pekerjaan sebagai balasan atas pekerjaannya. Untuk definisi ini digunakan istilah ajr, ujrah, dan ijarah. Kata ajara-hu dan ảjara-hu digunakan apabila seseorang memberikan imbalan atas pekerjaan orang lain. Istilah ini hanya digunakan pada hal-hal yang positif, bukan pada hal-hal yang negatif. Kata al-ajr (pahala) biasanya digunakan untuk balasan di akhirat, sedangkan kata ujrah (upah sewa) digunakan untuk balasan di dunia. ${ }^{15}$

Sedangkan al-ijarah dalam istilah para ulama ialah suatu akad yang mendatangkan manfaat yang jelas lagi mubah berupa suatu dzat yang ditentukan ataupun yang disifati dalam sebuah tanggungan, atau akad terhadap pekerjaan yang jelas dengan imbalan yang jelas serta tempo waktu yang jelas pula. ${ }^{16}$

Sedangkan Al-Ijarat (ijarah) berasal dari kata al-ajru yang arti menurut bahasanya ialah al-"iwadh yang arti dalam bahasa Indonesianya ialah ganti dan upah. Ijarah dalam bahasa Inggris disebut dengan kata "leasing”. Ijarah (leasing) didefinisikan sebagai "a lease contract as well as a hire contract. Al-ijarah (ijarah) yang disebut juga lease contract dan hire contract. ia berasal dari bahasa Arab al-ajr dan merupakan turunan dari kata kerja ajara, serta termasuk mashdar al-simâ'i. Secara bahasa ia berarti al-tsawâb (ganjaran), al-jazâ' al-hasan (balasan atas kebaikan), aljazâ' 'alâ al- 'amal (balasan atas perbuatan), dan al- 'iwadh (pergantian). ${ }^{17}$

Makna ijarah secara bahasa, sebagaimana dijelaskan dalam kitab al-Qamus alMuhith karya al-Firus Abadi, adalah jual-beli manfaat . Ijarah merupakan kata dasar (mashdar) yang semakna dengan kata al-ajr yang berarti perbuatan dan perilaku (alfi'li). Oleh karena itu makna ijarah secara etimologis adalah imbalan atas perbuatan, perilaku, dan upah atas pekerjaan yang diperbuat tersebut. Dalam kitab Maqayis alLughah ditegaskan bahwa makna ijarah secara bahasa menunjukkan salah satu rukunnya, yaitu ijarah yang merupakan imbalan kerja/jasa. ${ }^{18}$

Akad ijarah adalah jenis akad lazim, suatu akad yang mana salah satu pihak yang berakad tidak mempunyai hak fasakh, karena ia merupakan akad pertukaran, kecuali jika di dapati hal yang mewajibkan fasakh. Ijarah tidak menjadi fasakh dengan meninggalnya salah satu pihak yang berakad, pewaris memegang peranan warisan, apakah sebagai pihak muajjir atau musta'jir. Dan tidak menjadi fasakh dengan

${ }^{13}$ Zainal Abidin, "Akad Derivatif Dalam Transaksi Muamalah Kontemporer," Jurnal Penelitian Islam dan Keagamaan Islam, 10, no. 2 (2013): 340.

${ }^{14}$ Ibid.

15 Juni Sakinah, "Analisis Sistem Kerja Paramedis Kontrak Dan Pns Di Rsud Gayo Lues Ditinjau Dari Akad Ijarah Bi Al-“Amal,” Jurnal Hukum dan Keadilan, Jurista 7, no. 2 (2018): 173.

${ }^{16}$ Nasrulloh Ali Munif, "Analisis Akad Ijarah Muntahiya Bittamlik Dalam Perspektif Hukum Islam Dan Hukum Positif Di Indonesia," Jurnal Hukum Islam 4, no. 1 (2016): 59.

${ }^{17}$ Miko Polindi, "Filosofi Dan Perwujudan Prinsip Tauhîdullah, Dan Al-'AdâLah, Dalam Ijarah, Dan Ijarah Muntahia Bi-Tamlik (IMBT)," Baabu Al-Ilmi, Jurnal Ekonomi dan Perbankan Syariah 1, no. 1 (2017): 3.

${ }^{18}$ Jamaluddin, "Elastisitas Akad Al-Ijarah (Sewa-Menyewa) Dalam Fiqh Muamalah Persfektif Ekonomi Islam," At-Tamwil : Kajian Ekonomi Syariah 1, no. 1 (2019): 22. 
dijualnya barang (ain) yang disewakan untuk pihak penyewa atau lainnya, dan pembeli menerimanya jika ia bukan sebagai penyewa sesudah berakhirnya masa ijarah. ${ }^{19}$ Ijarah menjadi fasakh (batal) dengan hal adalah terjadi aib pada barang sewaan yang kejadiannya ditangan penyewa atau aib lama padanya, rusaknya barang yang disewakan, seperti rumah dan binatang yang menjadi ain, terpenuhinya manfaatyang diakadkan, atau selesainya pekerjaan, atau berakhirnya masa, kecuali jika terdapat halangan syar'I yang mencegah fasakh. Seperti jika masa ijarah tanah pertanian berakhir sebelum tanaman dipanen, maka ia tetap berada ditangan penyewa sampai masa ketam berakhir. Wafatnya salah seorang yang berakad, karena akad ijarah tidak dapat diwariskan. Menurut Hanafiyah. Sedangkan Jumhur Fuqaha berpendapat bahwa akad ijarah tidak batal karena wafatnya salah satu pihak yang berakad karena manfaat bisa diwariskan dan akad ijarah sama dengan jual beli. Dan Fuqaha Hanafiyah berpendapat bahwa : Boleh memfasakhkan ijarah, karena ada halangan syar'I sekalipun dari salah satu pihak. Seperti seseorang yang menyewa toko untuk berdagang, kemudian hartanya terbakar, atau dicuri atau dirampas atau bangkrut, maka ia berhak memfasakhkan ijarahnya.

Dalam Pelaksanaan prakteknya para masyarakat Kertagena Tengah ini tidak memberi nama dengan sebutan ijarah akan tetapi mereka menyebutnya dengan istilah "Nyewa Tokang". Secara teoritis sistem ijarah ini terbagi dua bentuk yaitu ijarah dan ijarah muntahiya bit tamlik. Penulis menuliskan bahwa sistem ijarah ini karena dalam prakteknya sesuai dengan teori ijarah, yaitu pemilik rumah menyewa jasa tukang bangunan tanpa diakhiri dengan pemindahan barang diakhir kontrak.

Menurut Fatwa Dewan Syari'ah Nasional No.09/DSN/MUI/IV/2000, ijarah adalah akad pemindahan hak guna (manfaat) atas suatu barang atau jasa dalam waktu tertentu melalui pembayaran sewa/upah, tanpa diikuti dengan pemindahan kepemilikan barang itu sendiri, dengan demikian dalam akad ijarah tidak ada perubahan kepemilikan, tetapi hanya pemindahan hak guna saja dari yang menyewakan kepada penyewa. ${ }^{20}$

Dilihat dari sisi obyeknya, akad ijarah dibagi menjadi dua bagian, yaitu: ${ }^{21}$ Ijarah manfaat (Al-Ijarah ala al-Manfa"ah) Hal ini berhubungan dengan sewa jasa, yaitu memperkerjakan jasa seseorang dengan upah sebagai imbalan jasa yang disewa. Pihak yang mempekerjakan disebut musta"jir, pihak pekerja disebut ajir, upah yang dibayarkan disebut ujrah. Misalnya, sewa menyewa rumah, kendaraan, pakaian dll. Dalam hal ini mu "jir mempunyai benda-benda tertentu dan musta "ji butuh benda tersebut dan terjadi kesepakatan antara keduanya, di mana mu"jir mendapatkan imbalan tertentu dari musta "jir dan musta"jir mendapatkan manfaat dari benda tersebut dan Ijarah yang bersifat pekerjaan (Alljarah ala Al-,,Amal) Hal ini berhubungan dengan sewa aset atau properti, yaitu memindahkan hak untuk memakai dari aset atau properti tertentu kepada orang lain dengan imbalan biaya sewa. Bentuk ijarah ini mirip dengan leasing (sewa) di bisnis konvensional. Artinya, ijarah ini

\footnotetext{
${ }^{19}$ Syamsul Hilal, "Urgensi Ijarah Dalam Prilaku Ekonomi Masyarakat,” Jurnal Hukum Ekonomi Syariah 5, no. 1 (2013): 7.

${ }^{20}$ Rosita Tehuayo, "Sewa Menyewa (Ijarah) Dalam Sistem Perbankan Syariah," Jurnal Hukum dan Syariah XIV, no. 1 (2018): 87.

${ }^{21}$ Harun Santoso and Anik, “Analisis Pembiayaan Ijarah Pada Perbankan Syariah,” Jurnal Ilmiah Ekonomi Islam 1, no. 2 (2015): 108.
} 
berusaha mempekerjakan seseorang untuk melakukan sesuatu. $M u$ "jir adalah orang yang mempunyai keahlian, tenaga, jasa dan lain-lain, kemudian musta"jir adalah pihak yang membutuhkan keahlian, tenaga atau jasa tersebut dengan imbalan tertentu. $M u$ "jir mendapatkan upah (ujrah) atas tenaga yang ia keluarkan untuk musta jir dan musta "jir mendapatkan tenaga atau jasa dari mu" "jir. Misalnya, yang mengikat bersifat pribadi adalah menggaji seorang pembantu rumah tangga, sedangkan yang bersifat serikat, yaitu sekelompok orang yang menjual jasanya untuk kepentingan orang banyak. (Seperti; buruh bangunan, tukang jahit, buruh pabrik, dan tukang sepatu.

Akad ijarah pada jasa tukang bangunan adalah ijarah 'amal yaitu pemberian imbalan atas suatu pekerjaan atau keahlian yang dilakukan seseorang. Dalam hal ini tukang bangunan (musta'jir) menyewa jasa dari pihak penyewa (mu'jir) untuk menyelesaikan bangunan rumah dan kemudian membayar upah (ujrah) sebagai pemberian imbalan atas pekerjaan yang dilakukan oleh pihak tukang bangunan (musta'jir).

Setelah tukang bangunan menyelesaikan bangunan rumah maka pihak pemilik rumah mempunyai kewajiban untuk membayar kepada tukang bangunan yang sudah disepakati bersama di awal akad. Hal ini sesuai dengan hadits Nabi yang diriwayatkan oleh Ibnu Majah yang artinya "Berikanlah olehmu upah orang sewaan sebelum keringatnya kering”. Pemilik rumah mendapatkan rumah yang sudah terselesaikan dan tukang bangunan mendapatkan upah.

Akad ijarah berakhir ketika pihak tukang bangunan menyelesaikan pekerjaannya dan menyerahkan kepada pihak pemilik rumah kemudian pemilik rumah membayar ujrah kepada pihak tukang bangunan. Ijarah menjadi batal (fasakh) bila ada hal-hal sebagai berikut yaitu, menurut ulama Hanafiah, ijarah dipandang habis dengan meninggalnya salah seorang yang akad, sedangkan ahli waris tidak memiliki hak untuk meneruskannya. Adapun menurut jumhur ulama, ijarah itu tidak batal, tetapi diwariskan, pembatalan akad, terjadinya kerusakan pada barang yang disewa. Akan tetapi, menurut jumhur ulama lainnya kerusakan pada barang sewaan tidak menyebakan habisnya ijarah, tetapi harus diganti selagi masih dapat diganti dan habis waktu, kecuali ada udzur. ${ }^{22}$

Hasil penelitian di Desa Kertagena Tengah, menemukan bahwa prosedur akad ijarah masih belum sepenuhnya sesuai dengan akad ijarah. Hal ini dapat dibuktikan melalui beberapa hal di antaranya akad. Ada macam bentuk akad yang dapat dilakukan yaitu perkataan, perbuatan, lisan dan tulisan.

Sedangkan akad yang dilakukan pada proyek pembangunan rumah di desa Kertagenah Tengah yaitu akad dengan lisan, kejelasan akad menjadi penentu tentang yang dibuat oleh tukang bangunan dan memperoleh hasil yang maskimal. Akad yang dilakukan ini tidak semuanya diperjelas dan tidak pula disertai dengan keterangan tulisan sehingga sering mengalami kesalahpahaman sehingga dampaknya pada hasil perjanjiannya misalnya model rumah yang diminta tidak sesuai dengan penjelasan pemilik rumah di awal akad. Selain itu juga tukang bangunan tidak maksimal dalam menjalankan kewajibannya seperti halnya memulai kerjanya tidak tepat pada waktu dan pengawasan dari pemilik rumah kurang sehingga berdampak hasil perjanjian yang

22 Laili Nur Amalia, "Tinjauan Ekonomi Islam Terhadap Penerapan Akad Ijarah Pada Bisnis Jasa Laundry," Jurnal Ekonomi dan Hukum Islam 5, no. 2 (2015): 178. 
tidak sesuai dengan yang diinginkan pemilik.

Hal ini tidak sesuai dengan definisi Ekonomi Islam yang dinyatakan oleh Ziauddin Ahmad bahwa Ekonomi Islam pada hakikatnya adalah upaya pengalokasian sumber-sumber daya untuk memproduksi barang dan jasa sesuai petunjuk Allah SWT untuk memperoleh Ridha-Nya. ${ }^{23}$ Kemudian dalam praktiknya tersebut antara tukang bangunan dengan pemilik rumah juga telah melanggar prinsip ekonomi islam, Ali Fikri menyebutkan beberapa prinsip (asas) dalam ekonomi Islam yaitu ${ }^{24}$ mengakui hak milik baik secara individual maupun secara umum, kebebasan ekonomi, kebersamaan dalam menanggung kebaikan (al takaful al ijtimai) Dalam prinsip ini mencakup; guna mewujudkan kebahagiaan baik pribadi maupun masyarakat, kepentingan pribadi tidak boleh merugikan kepentingan jemaah (orang banyak), kebersamaan dalam rangka menjaga kesatuan (ukhuwah), keakraban, ta awun, dan saling amanah dan berlaku objektif dan tidak diskriminatif.

Dengan demikian pihak tukang bangunan sebagai produsen jasa harus menjadikan hukum syariat sebagai dasar dan pedoman dalam menjalankan bisnis jasa tukang bangunan. Sebab tanpa berpedoman terhadap hukum syariat dikhawatikan banyak halhal yang menyimpang dari aturan agama Islam. Prosedur akad ijarah pada tukang bangunan terdapat 3 tahapan adalah pertama, proses akad yaitu pemilik rumah melakukan akad dengan kepala tukang bangunan mengenai tentang semua yang terkait dalam pembangunan rumah. Kedua, tukang bangunan menggarap rumah yang dibangun sesuai dengan permintaan pemilik rumah mulai dari awal penggarapan rumah sampai dengan rumah sudah selesai dilaksanakan. Ketiga, pembayaran dilakukan sesuai dengan kesepakatan di awal apakah pembayaran dilakukan harian, mingguan, bulanan atau di akhir kontrak.

\section{Tinjauan Ekonomi Islam Terhadap Penerapan Akad Ijarah pada Tukang Bangunan.}

Ijarah memiliki 4 (rukun) yaitu, 'aqid (orang yang berakad), shigat akad, ujrah (upah) dan manfaat . Dalam referensi lain disebutkan bahwa 'aqid terdiri dari 2 pihak, yang disebut mu'jir dan musta'jir, serta rukun yang keempat adalah barang yang disewakan. Mu'jir dan musta'jir. Mu'jir merupakan orang yang menerima upah dan yang menyewakan, sedangkan musta'jir merupakan orang yang menerima upah untuk melakukan sesuatu dan yang menyewa sesuatu. Shigat, ijab kabul merupakan akad yang dilakukan antara mu'jir dan musta'jir. Ujrah (upah), merupakan upah disyaratkan diketahui jumlahnya oleh kedua belah pihak, baik dalam sewa-menyewa maupun dalam upah-mengupah. Objek Ijarah, yaitu barang yang disewakan atau sesuatu yang dikerjakan dalam upah-mengupah. ${ }^{25}$

Menurut jumhur ulama, bahwa rukun al-ijārah ada empat, yaitu: 'Aqiq (Mu'jir Dan Musta'jir), Sighat akad, Ujrah dan Ma'qud Alaih.

\section{a. Aqid (Mu'jir dan Musta'jir)}

Al-Aqid adalah al-ismul fa'il (isim Fa'il) dari aqoda dan artinya adalah orang

\footnotetext{
${ }^{23}$ Mohamad Hidayat, An Introduction to The Sharia Economic (Jakarta: Zikrul Hakim, 2010), h.27.

${ }^{24}$ Siti Saleha Madjid, "Prinsip-Prinsip (Asas-Asas) Muamalah," Jurnal Hukum Ekonomi Syariah2 2, no. 1 (2018): 16.

${ }^{25}$ Danis Amwalul Fikki, "Penerapan Akad Ijarah Pada Produk Pembiayaan Pengurusan Porsi Haji Di KSPPS Kopena Pekalongan Ditinjau Dari Fatwa DSN-MUI," Jurnal Ekonomi Manajemen dan Bisnis Islam 1, no. 1 (2019): 47.
} 
yang melaksanakan aqad ( عقد فهو عاقد ). Keberadaan Al-Aqid sangat penting dalam sebuah akad. Akad tidak akan terjadi dan memiliki kekuatan hukum bila tidak ada al-Akid, sama seperti tidak akan terjadi akad bila tidak ada shighoh ijab-qobul. ${ }^{26}$

Agar suatu akad dapat dipandang sebagai akad yang sahih, salah satu syaratnya yaitu bahwa para pihak yang berakad (Aqid) disyaratkan harus memiliki wilayah dan ahliyyah yang sempurna. Wilayah (kekuasaan) adalah kekuasaan seseorang untuk melakukan tindakan hukum berupa akad, sedangkan ahliyyah yang sempurna berarti kelayakan seseorang untuk menerima hak dan melaksanakan kewajiban. ${ }^{27}$

Unsur-unsur yang terdapat dalam akad ijarah diantaranya mu'jir dan musta'jir. Mu'jir adalah orang yang menyewa jasa yaitu Pemilik rumah sedangkan Musta'jir adalah orang yang disewa jasanya untuk melakukan penyelesaian bangunan yaitu pihak tukang bangunan.

Syarat mu'jir dan musta'jir dalam melakukan akad ijarah adalah orang yang sudah baligh, berakal sehat. Apabila syarat tersebut tidak dipenuhi, maka akad yang dilakukan tidak sah. Semisal orang yang melakukan akad adalah anak kecil atau orang gila. ${ }^{28}$

\section{b. Sighat Akad}

Pernyataan kehendak yang biasanya disebut sebagai sighat akad, yakni suatu ungkapan para pihak yang melakukan akad berupa ijab dan qabul. Ijab adalah suatu pernyataan janji atau penawaran dari pihak pertama untuk melakukan atau tidak melakukan sesuatu. qabul adalah suatu pernyataan menerima dari pihak kedua atas penawaran yang dilakukan oleh pihak pertama. ${ }^{29}$

Lafadz (sighat akad) adalah dengan cara bagaimana ijab dan kabul yang merupakan rukun-rukun akad itu dinyatakan. Shigat akad dapat dilakukan secara lisan, tulisan, atau isyarat yang memberi pengertian dengan jelas tentang adanya ijab dan kabul dan dapat juga berupa perbuatan yang telah menjadi kebiasaan dalam ijab dan qabul. ${ }^{30}$

Yang dimaksud dengan shighat transaksi ijarah adalah sesuatu yang digunakan untuk mengungkapkan maksud muta'aqidain (dua pihak yang melakukan transaksi), yakni berupa lafal atau sesuatu yang mewakilinya, seperti lafal menyewa, mempekerjakan, atau semisal ungkapan "Aku meminjamkan rumah ini kepadamu selama sebulan dengan bayaran sekian." Hal ini karena pinjam-meminjam dengan upah berarti ijarah. Bisa juga dengan lafal "Aku berikan manfaatnya kepadamu selama sebulan dengan harga sekian" atau "Aku berdamai denganmu agar kamu menghuni rumah ini selama sebulan dengan harga sekian". Kemudian orang yang menyewa berkata "Aku terima". Jika muta'aqidain mengerti maksud lafal shighah, maka ijarah telah sah apapun lafal yang digunakan

\footnotetext{
${ }^{26}$ Djohar Arifin, "Substansi Akad Dalam Transaksi Syariah,” Jurnal Kajian Ekonomi dan Perbankan Syariah 6, no. 1 (2014): 171.

${ }^{27}$ Muhammad Rifqi Hidayat, “Analisis Fikih Klasik Terhadap Badan Hukum Sebagai Aqid,” Jurnal Ekonomi Syariah dan Hukum Ekonomi Syariah 2, no. 2 (2015): 50.

${ }^{28}$ Hendi Suhendi, Fiqh Muamalah (Jakarta: Raja Grafindo, 2005), h. 117.

29 Afdawaiza, "Terbentuknya Akad Dalam Hukum Perjanjian Islam," Jurnal Hukum Islam XVIII (2008): 188.

30 Meri Piryanti, “Akibat Hukum Perjanjian (Akad) Dan Terminasi Akad," Jurnal Studi Islam dan Muamalah 2, no. 1 (2014): 7.
} 
karena Syari' (pembuatan syariecat, Allah/Rasul-Nya) tidak membatasi lafal transaksi, tetapi hanya menyebutnya secara umum.

Dalam jasa tukang bangunan Sighat Akad tidak dinyatakan dengan ucapan yang jelas, namun diantara kedua belah pihak saling merelakan (ridha), hal ini sebagaimana definisi ijab dan kabul yaitu suatu perbuatan atau pernyataan untuk menunjukkan suatu keridhaan dalam berakad diantara dua orang lebih.

Ijab adalah suatu pernyataan janji atau penawaran dari pihak pertama untuk melakukan atau tidak melakukan sesuatu. Qabul adalah suatu pernyataan menerima dari pihak kedua atas penawaran yang dilakukan oleh pihak pertama

Ijab dan qabul sendiri dapat dilakukan dengan cara-cara berikut ini: ${ }^{31}$ pertama, Lisan. Para pihak mengungkapkan kehendaknya dalam bentuk perkataan secara jelas. Dalam hal ini akan sangat jelas bentuk ijab dan qabul yang dilakukan oleh para pihak,. kedua tulisan. Adakalanya, suatu perikatan dilakukan secara tertulis. Hal ini dapat dilakukan oleh para pihak yang tidak dapat bertemu langsung dalam melakukan perikatan, atau untuk perikatan-perikatan yang sifatnya lebih sulit, seperti perikatan yang dilakukan oleh suatu badan hukum. Akan ditemui kesulitan apabila suatu badan hukum melakukan perikatan tidak dalam bentuk tertulis, karena diperlukan alat bukti dan tanggung jawab terhadap orangorang yang bergabung dalam satu badan hukum tersebut. Ketiga Isyarat. Suatu perikatan tidaklah hanya dilakukan oleh orang normal, orang cacat pun dapat melakukan suatu perikatan (akad). Apabila cacatnya adalah berupa tuna wicara, maka dimungkinkan akad dilakukan dengan isyarat, asalkan para pihak yang melakukan perikatan tersebut memiliki pemahaman yang sama. Keempat Perbuatan. Seiring dengan perkembangan kebutuhan masyara'at, kini perikatan dapat pula dilakukan dengan cara perbuatan saja, tanpa secara lisan, tertulis, ataupun isyarat. Hal ini dapat disebut dengan ta'athi atau mu'athah (saling memberi dan menerima). Adanya perbuatan memberi dan menerima dari para pihak yang telah saling memahami perbuatan perikatan tersebut dan segala akibat hukumnya. Hal ini sering terjadi pada proses jual-beli di supermarket yang tidak ada proses tawar menawar. Pihak pembeli telah mengetahui harga barang yang secara tertulis dicantumkan pada barang tersebut. Pada saat pembeli datang ke meja kasir, menunjukkan bahwa diantara mereka akan melakukan perikatan jual beli.

Ijab qabul yang dilakukan antara pemilik rumah dan tukang bangunan adalah dengan perkataan. Pemilik rumah menjelaskan kepada tukang bangunan dalam pelaksanaan membangun rumah tersebut dengan menggunakan akad lisan. Kerelaan kedua belah pihak dapat dilihat dari hasil penelitian dimana pihak tukang bangunan menyelesaikan bangunan tersebut dapat ditunjukkan ketika pemilik rumah membayar jasa tukang bangunan.

Selain itu terdapat ketentuan waktu dalam menyewa tukang bangunan, pihak pemilik rumah menyatakan kepada tukang bangunan mereka dapat upah ketika bangunan tersebut sudah diselesaikan. Ketentuan waktu dalam menyelesaikan bangunan rumah.

${ }^{31}$ Ash-Shawi. Shalah and Abdullah Al-mushlih, Fikih Ekonomi Keuangan Islam, (Terjemahan) (Jakarta: Darul Haq, 2008), h.27. 
Tabel 1. Ketentuan Waktu Penyelesaian Rumah

\begin{tabular}{lcc}
\hline Ketentuan waktu & Frekuensi & Presentase \\
& & $(\%)$ \\
\hline Tidak ditentukan & 2 & $80 \%$ \\
\hline 1 bulan & 1 & $20 \%$ \\
\hline Total & 3 & $100 \%$
\end{tabular}

Sumber Data: Olahan Hasil Wawancara Tahun 2019

Dari Tabel 1. dapat dilihat bahwa pemilik rumah tidak menentukan dalam penyelesaian rumah.

c. Ujrah

Ujrah (uang sewa atau upah), yaitu berupa uang yang diambil dari manfaat barang yang disewakan dan atas pekerjaan yang telah dilakukan. ${ }^{32}$

Menurut ulama Hanafiyah, rukun ujrah itu hanya satu, yaitu ijab (ungkapan menyewakan) dan qabul (persetujuan terhadap sewa menyewa). Akan tetapi, jumhur ulama mengatakan bahwa rukun ujrah itu ada empat, yaitu: a. Orang yang berakad b. Sewa atau imbalan c. Manfaat d. Shighat (ijab-qabul). ${ }^{33}$

Dalam transaksi yang menggunakan akad ijarah, apabila secara rukun dan syarat telah terpenuhi makan pemberian sewa upah (ujrah) dalam transaksi ini adalah hak yang harus diberikan kepada yang berhak. Semisal, seorang pemborong proyek bangunan mempekerjakan orang sewaannya, maka pemborong tersebut memiliki kewajiban untuk memberikan sewa upah (ujrah) kepada orang sewaan tersebut sebagai imbalan dari hasil kerjanya. ${ }^{34}$

Ujrah didalam penelitian ini ialah upah yang diberikan oleh pemilik rumah pengguna jasa (mu'jir) selaku orang yang menyewa jasa kepada orang yang disewa tenaganya untuk melakukan pekerjaan bangunan yaitu pihak tukang bangunan (musta'jir). Kebijakan ujrah atau biaya tukang bangunan yang diterapkan oleh masing-masing tukang bangunan berbeda sesuai dengan sistem yang mereka gunakan, dimana ujrah yang dibayarkan kepada tukang bangunan ketika diselesaikan selama 30 hari maka $70 \%$.

Tabel 2. Pembayaran Biaya Tukang Bangunan

\begin{tabular}{|c|c|c|c|}
\hline $\begin{array}{c}\text { Pembayaran } \\
\text { Tukang Bangunan }\end{array}$ & Biaya & Frekuensi & $\begin{array}{l}\text { Presentase } \\
(\%)\end{array}$ \\
\hline Harian & & 1 & $30 \%$ \\
\hline Mingguan & & - & - \\
\hline Bulanan & & - & - \\
\hline Diakhir Kontrak & & 3 & $70 \%$ \\
\hline Total & & 4 & $100 \%$ \\
\hline
\end{tabular}

${ }^{32}$ Suhendi, Fiqh Muamalah, h.117.

${ }^{33}$ Hendy Herijanto and Muhammad Nurul Hafiz, "Pengupahan Perspektif Ekonomi Islam Pada Perusahaan Outsourcing," Journal of Islamic Economics,Business and Finance 7, no. 1 (2016): 16.

${ }^{34}$ Polindi, "Filosofi Dan Perwujudan Prinsip Tauhîdullah, Dan Al-'AdâLah, Dalam Ijarah, Dan Ijarah Muntahia Bi-Tamlik (IMBT)." 
Dari Tabel 2. dapat dilihat bahwa pemilik rumah melakukan pembayaran ujrah diakhir kontrak ketika mereka menyelesaikan bangunan.

\section{d. Ma'qud 'Alaih}

Ma'qud 'Alaih adalah objek akad atau benda-benda yang dijadikan akad yang bentuknya tampak dan membekas. Barang tersebut dapat berbentuk harta benda, seperti barang dagangan, benda bukan harta, seperti akad dalam pernikahan, dan dapat pula berbentuk suatu kemanfaatan, seperti dalam masalah upah-mengupah, dan lain- lain. ${ }^{35}$ Adanya kejelasan dalam barang tersebut, akan menghilangkan pertentangan antara 'Aqid. Untuk mengetahui kejelasan barang tersebut adalah, dengan menjelaskan manfaatnya, pembatasan waktu serta jenis pekerjaannya. $^{36}$

Ada 5 syarat bagi obyek akad ( al-ma'qud alaih ), yaitu obyek akad harus ada ketika terjadi peristiwa akad, obyek akad harus sesuai dengan syariat ( masyru'), obyek akad harus dapat diserahkan pada saat akad, obyek akad harus maklum dan dapat diketahui oleh Al-Aqid, obyek akad harus suci tidak najis atau mutanajjis ${ }^{37}$

Ma'qud 'Alaih dalam penelitian ini adalah sesuatu yang dikerjakan yaitu menyelesaikan bangunan yang telah dipercayakan kepada pihak pemilik rumah. Syarat dari ma'qud alaih telah memenuhi obyek akad yaitu suatu yang dikerjakan mubah/tidak haram dan dapat diserah terimakan.

Pemilik rumah mendapatkan manfaat dari pihak tukang bangunan menyelesaikan bangunan. Kemanfaatan yang dimaksud mubah dan tidak diharamkan adalah kemanfaatan yang tidak ada larangan dalam syara'. Kemanfaatan itu tidak sah apabila menyewakan tenaga (orang) dalam hal kemaksiatan, karena maksiat wajib ditinggalka. Hal ini sebagaimana dijelaskan dalam firman Allah Swt dalam surat Al-Maidah ayat 90.

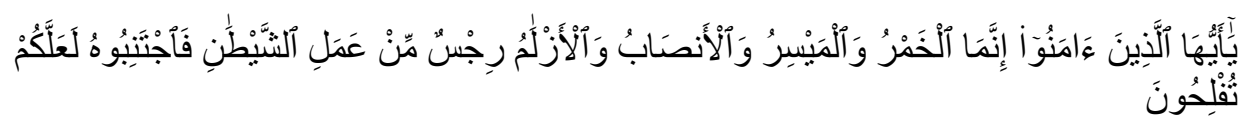

Artinya: "hai orang-orang yang beriman, sesungguhnya (meminum) khamar, berjudi, (berkurban untuk) berhala, mengundi nasib dengan panah, adalah rijsun termasuk perbuatan setan. Maka jauhilah perbuatan-perbuatan itu agar kamu mendapat keberuntungan". 38

Penerapan akad ijarah pada jasa tukang bangunan yang ditinjau dalam ekonomi Islam sudah sesuai dengan ketentuan-ketentuan syara' dengan adanya ketentuan kerja, bentuk kerja, dan ujrah yang sudah jelas serta jasa yang disewa merupakan jasa yang mubah. Akan tetapi dalam prosedur pembangunan rumah harus diperhatikan dalam hal kualitas dan kuantitas seperti yang dipaparkan di atas masih ada perilaku yang kurang menyempurnakan terhadap akad ijarah misalnya ketidakjelasan akad baik dari model

35 Alfata, "Proses Penimbangan Ikan Di Tempat Pelelangan Ikan Lampulo Kota Banda Aceh Dalam Perspektif Ma’qud ‘Alaih,” Jurnal Kajian Ilmu Hukum dan Syariah 3, no. 2 (2018): 270.

${ }^{36}$ Nur Aksin, "Upah Dan Tenaga Kerja (Hukum Ketenagakerjaan Dalam Islam)," Jurnal Meta Yuridis 1, no. 2 (2018): 76.

${ }^{37}$ Syafi'i, Fiqh Muamalah, h.58.

38 Departemen Agama, Al-Qur'an Dan Terjemahannya (Surabaya: PT.Elba Fitrah Mandiri Sejahtera, 2012), h.123. 
rumah, jangka waktu penyelesaian rumah dan permulaan jam kerja.Begitu juga dalam perjanjian akad dimana dilakukan dengan perjanjian secara lisan, akibatnya membuka peluang masalah diakhir setelah selesai kontrak.

\section{Simpulan}

Berdasarkan hasil penyajian yang dilakukan oleh penulis didalam penelitian yang berjudul Sistem Operasional Akad Ijarah Pada Kinerja Tukang Bangunan Menurut Ekonomi Islam Di Desa Kertagena Tengah Kabupaten Pamekasan, ditemukan suatu kesimpulan bahwa akkad yang terjalin antara mu'jir pemilik rumah dengan musta'jir tukang bangunan hanya akad lisan bukan tulisan. Sehingga jika ada komplain dari mu'jir dan musta'jir tidak memiliki bukti yang kuat. Padahal dalam Islam setiap bermuamalah atau melakukan transaksi hendaknya ditulis.

Kemudian berikutnya didalam melaksanakan tugasnya tukang bangunan sering melalaikan kewajibannya yaitu pada waktu memulai dan mengakhiri jam kerja. Dimana Setelah terjadi kesepakatan antara mu'jir dan musta'jir masing-masing pihak harus menjalankan tugasnya secarah sungguh-sungguh. Namun yang terjadi di Desa Kertagena Tengah ini tukang bangunan memulai kerjanya tidak tepat waktu yang seharusnya dimulai pada jam 07.00 sampai jam 16.00 akan tetapi dimulai setelah jam 07.00 dan berhenti sebelum jam 16.00. Tentunya dalam hal ini memperlambat proses penyelesaian pembangunan rumah dan memakan biaya yang cukup banyak, sehingga keadaan tersebut akan marugikan mu'jir

Tidak hanya itu saja adanya suatu permasalahan dimana hasil pekerjaan yang dilakukan oleh tukang bangunan tidak sesuai dengan kriteria apa yang diinginkan oleh pemilik rumah.

Agar pemasalahan ini tidak terjadi lagi Diharapkan kedua belah pihak dalam melakukan akad tidak hanya dilakukan secara lisan saja, tetapi disertai dengan keterangan tulisan atau menghadirkan saksi. Kemudian pada pelaksanaannya mulai dari awal sampai akhir mu'jir selalu memberikan pengawasan dan arahan kepada musta'jir supaya tidak terjadi kesalahpahaman baik dari jam kerja, model bangunan dan sebagainya. Selanjutnya kedua belah pihak diharapkan menjalankan tugasnya masing-masing dengan jujur dan amanah, sehingga tidak ada salah satu pihak yang dirugikan. mu'jir maupun musta'jir harus mempunyai ketaatan dalam menjalankan tugasnya seperti yang diajarkan oleh konsep muamalah.

\section{Daftar Pustaka}

Abidin, Zainal. "Akad Derivatif Dalam Transaksi Muamalah Kontemporer." Jurnal Penelitian Islam dan Keagamaan Islam, 10, no. 2 (2013): 340.

Afdawaiza. "Terbentuknya Akad Dalam Hukum Perjanjian Islam.” Jurnal Hukum Islam XVIII (2008): 188.

Agama, Departemen. Al-Qur'an Dan Terjemahannya. Surabaya: PT.Elba Fitrah Mandiri Sejahtera, 2012.

Aksin, Nur. "Upah Dan Tenaga Kerja (Hukum Ketenagakerjaan Dalam Islam)." Jurnal Meta Yuridis 1, no. 2 (2018): 76.

Alfata. "Proses Penimbangan Ikan Di Tempat Pelelangan Ikan Lampulo Kota Banda Aceh 
Dalam Perspektif Ma'qud 'Alaih.” Jurnal Kajian Ilmu Hukum dan Syariah 3, no. 2 (2018): 270.

Amalia, Laili Nur. "Tinjauan Ekonomi Islam Terhadap Penerapan Akad Ijarah Pada Bisnis Jasa Laundry.” Jurnal Ekonomi dan Hukum Islam 5, no. 2 (2015): 178.

Arifin, Djohar. "Substansi Akad Dalam Transaksi Syariah." Jurnal Kajian Ekonomi dan Perbankan Syariah 6, no. 1 (2014): 171.

Budiwati, Septarina. "Akad Sebagai Bingkai Transaksi Bisnis Syariah.” Jurnal Jurisprudence2 7, no. 2 (2017): 153.

Fikki, Danis Amwalul. "Penerapan Akad Ijarah Pada Produk Pembiayaan Pengurusan Porsi Haji Di KSPPS Kopena Pekalongan Ditinjau Dari Fatwa DSN-MUI.” Jurnal Ekonomi Manajemen dan Bisnis Islam 1, no. 1 (2019): 47.

Hanafiah, HM. "Akad Jual Beli Dalam Tradisi Pasar Terapung Masyarakat Banjar.” Jurnal Pemikiran Islam 15, no. 1 (2015): 203.

Herijanto, Hendy, and Muhammad Nurul Hafiz. "Pengupahan Perspektif Ekonomi Islam Pada Perusahaan Outsourcing." Journal of Islamic Economics,Business and Finance 7, no. 1 (2016): 16.

Hidayat, Mohamad. An Introduction to The Sharia Economic. Jakarta: Zikrul Hakim, 2010.

Hidayat, Muhammad Rifqi. "Analisis Fikih Klasik Terhadap Badan Hukum Sebagai Aqid." Jurnal Ekonomi Syariah dan Hukum Ekonomi Syariah 2, no. 2 (2015): 50.

Hilal, Syamsul. "Urgensi Ijarah Dalam Prilaku Ekonomi Masyarakat." Jurnal Hukum Ekonomi Syariah 5, no. 1 (2013): 7.

Jamaluddin. "Elastisitas Akad Al-Ijarah (Sewa-Menyewa) Dalam Fiqh Muamalah Persfektif Ekonomi Islam." At-Tamwil : Kajian Ekonomi Syariah 1, no. 1 (2019): 22.

Koem, Fatillah D. "Tinjauan Ekonomi Islam Terhadap Jasa Profesi Tukang Parkir (Studi Kasus Pasar 45 Kota Manado).” Jurnal Ilmiah Al-Syir'ah 12, no. 1 (2014): 1.

Madjid, Siti Saleha. "Prinsip-Prinsip (Asas-Asas) Muamalah." Jurnal Hukum Ekonomi Syariah2 2, no. 1 (2018): 16.

Moleong, Lexy J. Metodologi Penelitian Kualitatif. Bandung: PT Remaja Rosdakarya, 2006.

Munif, Nasrulloh Ali. "Analisis Akad Ijarah Muntahiya Bittamlik Dalam Perspektif Hukum Islam Dan Hukum Positif Di Indonesia.” Jurnal Hukum Islam 4, no. 1 (2016): 59.

Piryanti, Meri. "Akibat Hukum Perjanjian (Akad) Dan Terminasi Akad.” Jurnal Studi Islam dan Muamalah 2, no. 1 (2014): 7.

Polindi, Miko. "Filosofi Dan Perwujudan Prinsip Tauhîdullah, Dan Al-'AdâLah, Dalam Ijarah, Dan Ijarah Muntahia Bi-Tamlik (IMBT).” Baabu Al-Ilmi, Jurnal Ekonomi dan Perbankan Syariah 1, no. 1 (2017): 3.

Qardhawi, Yusuf. Norma Dan Etika Ekonomi Islam. Jakarta: Gema Insani Press, 2001.

Sakinah, Juni. “Analisis Sistem Kerja Paramedis Kontrak Dan Pns Di Rsud Gayo Lues 
Ditinjau Dari Akad Ijarah Bi Al-“Amal.” Jurnal Hukum dan Keadilan, Jurista 7, no. 2 (2018): 173.

Santoso, Harun, and Anik. "Analisis Pembiayaan Ijarah Pada Perbankan Syariah.” Jurnal Ilmiah Ekonomi Islam 1, no. 2 (2015): 108.

Setiawan, Firman. "Al-Ijarah Al-A'mal Al-Mustarakah Dalam Perspektif Hukum Islam." Jurnal Ekonomi dan Keuangan Islam 1, no. 2 (2015): 105.

Shalah, Ash-Shawi., and Abdullah Al-mushlih. Fikih Ekonomi Keuangan Islam, (Terjemahan). Jakarta: Darul Haq, 2008.

Sharif, Chaudhry Muhammad. Sistem Ekonomi Islam. Jakarta: Kencana, 2012.

Solihah, Ajeng Mar'atus. "Penerapan Akad Ijarah Pada Pembiayaan Multijasa Dalam Perspektif Hukum Islam.” Jurnal Hukum Bisnis Islam 6, no. 1 (2014): 107.

Suhendi, Hendi. Fiqh Muamalah. Jakarta: Raja Grafindo, 2005.

Syafi'i, Rachmat. Fiqh Muamalah. Bandung: CV Pustaka Setia, 2014.

Tehuayo, Rosita. "Sewa Menyewa (Ijarah) Dalam Sistem Perbankan Syariah.” Jurnal Hukum dan Syariah XIV, no. 1 (2018): 87.

Yunus, Muhammad, Fahmi Fatwa Rosyadi Satria Hamdani, and Gusti Khairina Shofia. "Tinjauan Fikih Muamalah Terhadap Akad Jual Beli Dalam Transaksi Online Pada Aplikasi Go-Food.” Jurnal Ekonomi dan Keuangan Syariah 2, no. 1 (2018): 146.

Yusuf, Muhammad Syahrial. Meraih Keajaiban Rezeki Dengan Wirausaha. Jakarta: Erlangga, 2013.

Zainollah, and Fakhruzy Fakhruzy. "Penundaan Pembayaran Upah Pekerja Di Pabrik Sandal UD. Nusantara Desa Pasanggar Kecamatan Pegantenan Kabupaten Pamekasan Perspektif Hukum Islam.” Jurnal Hukum Ekonomi Islam Indonesia 1, no. 1 (2019): 21. 